\title{
RIVALITAS STRATEGI MARITIM CHINA DAN INDIA \\ DI SELAT MALAKA
}

\begin{abstract}
Ayusia Sabhita Kusuma ${ }^{1}$
"Jika engkau mengetahui dirimu dan mengetahui musuh-musuhmu, maka dalam seribu perang pun engkau tak akan terkalahkan” (Sun Tzu)

"Whosoever commands the sea commands the trade; whosoever commands the trade of the world commands the riches of the world, and consequently the world itself" (Great Britain's Sir Walter Raleigh)
\end{abstract}

\begin{abstract}
Regarding the significance of Malacca Strait as a key maritime's "choke-point" passage between Indian and Pacific oceans, some major countries become dependence with the security and safety in Malacca Sea Lines of Communications (SLOC). China and India are two states-user of Malacca Strait which sharing common interests of economic, maritime trade and energy supplies. The problem is, as a regional power of each region, India and China have an ambition to control the security of Malacca's Strait. China which is more dependent with its $80 \%$ trade and energy supply through Malacca Strait, facing "Malacca dilemma" regarding the issue. Then, with the strategy of "string of pearls" and the modernization of of People's Liberation Army Navy (PLAN), China became assertive to save its interests. India, which has control over Indian Ocean then feel threaten by China's activities around Malacca Strait and Indian Ocean. India starts and enhances the development of Andaman Nicobar Command with US support near Malacca Straits to counter China's development. This paper will analyze the development of China's dan India's maritime strategy rivalry in Malacca Straits with the concepts of balance of power and maritime strategy.
\end{abstract}

Keywords: Malacca Strait, China's maritime strategy, India's maritime strategy, rivalry, balance of power.

\section{Pendahuluan}

Sejak berabad-abad, Selat Malaka menjadi jalur perniagaan bangsa-bangsa Romawi, China, Persia, Yunani dan Arab di kawasan Asia Tenggara. Pada era kolonialisasi, Selat Malaka dikuasai Belanda, Portugis dan Inggris untuk menghubungkan
Afrika dan India dengan China, Jepang dan Asia Tenggara sebagai jalur pengangkutan komoditi hasil eksploitasi, penjajahan maupun perdagangan. Hingga sekarang, Selat Malaka menjadi jalur pelayaran internasional antara Timur dan Barat yang penting karena sepertiga dari perdagangan dunia dan separuh dari

\footnotetext{
${ }^{1}$ Staf Pengajar Program Studi Hubungan Internasional, FISIP Universitas Jenderal Soedirman. Email: kusumabumi@gmail.com
} 
pengangkutan minyak atau sumber energi dunia, menggunakan akses melalui Selat Malaka (Percival 2005 \& Pena 2009 dalam Kusuma 2013). Sebagai urat nadi perekonomian dan jalur pelayaran internasional yang padat, tentu saja keamanan dan keselamatan (security and safety) pelayaran di Selat Malaka menjadi salah satu agenda negara-negara besar di Asia hingga Amerika Serikat. Terutamanya sejak kebangkitan ekonomi negara-negara di Asia seperti Jepang, China dan India, yang ditandai dengan adanya ekspansi ekonomi dan interdependensi kawasan Asia Timur dengan kawasan lain. Meningkatnya liberalisasi perdagangan, volume ekspor-impor negaranegara industri ini ke seluruh kawasan di dunia termasuk Asia Tenggara, juga dibarengi dengan meningkatnya kebutuhan akan pasokan sumber energi dan kebutuhan keamanan lalulintas perdagangannya.

Posisi Selat Malaka sebagai jalur pelayaran internasional adalah strategis sebagai rute efektif dalam Sea Lines of Communication (SLOC) dan Sea Lines of Transportation (SLOT) bagi keamanan pasokan dan pengangkutan sumber energi negara-negara besar dengan kawasan Asia Barat maupun Afrika. Tara Singh (2012) secara lebih lanjut dalam artikelnya menyebutkan ada tiga kepentingan negaranegara besar di Selat Malaka yaitu kaitannya dengan kekuatan persenjataan dan proyeksi kekuatan militer, kepentingan komersil atau perdagangan melalui jalur maritim, dan eksploitasi sumber daya kelautan. Pertarungan keseimbangan kekuatan (balance of power) di Selat ini kemudian menjadi kajian yang menarik dalam konteks keamanan regional maupun ekstraregional.

Bagi dua kekuatan besar ekstraregional Asia Tenggara, yaitu China dan India, keamanan Selat Malaka menjadi salah satu prioritas dalam kepentingan geostrategik di Asia Tenggara. Dua negara pengguna selat ini (strait user), sama-sama membutuhkan keamanan Selat Malaka sebagai penghubung ekspor-impor barang dan pasokan energi dari Afrika dan Timur Tengah, Asia Tenggara, Asia Timur dan Asia Pasifik. Sedangkan, Selat Malaka sendiri termasuk satu daripada choke points zona maritim di dunia yang paling berbahaya dan hotspot kejahatan transnasional yang terorganisir (Gerard\&Webb, 2006).

Perekonomian China tergantung pada keamanan di Selat Malaka karena sekitar 80\% impor sumber energi dan perdagangan China melalui Selat Melaka, sehingga strategi pengamanan Selat Malaka menjadi satu agenda penting keamanan dan pertahanan China. Secara lebih luas, China menginginkan keamanan jalur laut pengangkutan sumber energinya (SLOC dan SLOT) mulai dari Babel-Mandeb, Selat Hormuz, ke Selat Malaka hingga melewati Laut China Selatan dalam alur "string of pearls".

Ancaman-ancaman terhadap keamanan maritim mencakup pembajakan, perompakan dan terorisme maritim. China menghadapi apa yang disebut "Malacca Dilemma" berkaitan 
dengan keamanan Selat Malaka. Banyaknya tantangan dan ancaman keamanan maritim terhadap lalulintas sumber energi tersebut, tidak dibarengi dengan pengawalan keamanan yang potensial dan efektif dari China. Hal ini bukan semata-mata karena ketidakmampuan militer angkatan laut China, akan tetapi justru pengerahan kekuatan militer semacam itu bisa menimbulkan "dilema keamanan" lebih lanjut di Selat Malaka mengingat sengketa territorial China di kepulauan Spratlys maupun Laut China Selatan (Storey, 2006).

Proses pengawalan dan keamanan kepentingan China di Selat Malaka juga tak lepas dari bagaimana China mempersepsikan upaya penghambatan dan pembendungan negara-negara besar (terutamanya Amerika Serikat) maupun negara-negara pantai dalam upaya pencapaian agenda keamanan energi China. Seperti pernyataan $\mathrm{Hu}$ Jintao pada November 2003, “ Some big powers have tried to control and meddle in the Strait of Malacca shipping lanes... [We need] a new strategy. . . to ensure energy security"'(Khurana, 2011:56).

Tidak hanya lalu lintas perdagangan dan sumber energi, Selat Malaka juga menjadi lalu lintas perdagangan persenjataan, misil balistik maupun senjata nuklir bagi China mengingat upaya memodernisasi persenjataan dan masih maraknya konflik yang terjadi dengan beberapa negara menyangkut kemerdekaan wilayah maupun klaim teritori.

Signifikansi Selat Malaka bagi India ialah menjadi laut penghubung (sea-link) dari Samudera India melalui laut Andaman dengan Samudera Pasifik. Kepentingan India dalam keamanan jalur laut dari Teluk Benggala sampai ke laut Andaman dan Selat Melaka terutamanya adalah untuk mengamankan aset ekonomi kekayaan alam pulau Andaman dan Nicobar sebagai bagian ZEE (Zona Ekonomi Eksklusif) dan landas kontinen (Singh, 2008: 3 -4). Selat Malaka menjadi rute terpendek menghubungkan teluk Persia dengan Asia Timur dan Amerika Serikat, sehingga menjadi choke point penting di Samudera Hindia.

Seperti halnya China, kepentingan India di Selat Malaka juga berkaitan dengan kepentingan ekonomi melalui lalu lintas perdagangan dan sumber energi dimana sekitar $30 \%$ per tahun barang-barang perdagangan India melewati Selat ini. Kepentingan India di Selat Malaka ini juga merujuk pada menguatnya hubungan India dengan negaranegara di Asia Tenggara baik secara ekonomi, politik maupun kerjasama militer yang diperkuat dengan kebijakan "look east policy"dan "act east policy" untuk meluaskan pengaruh India di kawasan ini. Selat Malaka sendiri juga menjadi media persaingan India terhadap ancaman perluasan pengaruh China di Asia Tenggara. Aliansi India bersama Amerika Serikat, Jepang dan Australia melalui skema Proliferation Security Inisiative (PSI) dalam kerangka Regional Maritime Security Proliferation (RMSI), vital kaitannya untuk memata-matai aktivitas China, Korea Utara dan Pakistan di Asia Pasifik (Prabhakar, 2009: 
226). Mengingat laut juga menjadi media lalu lintas weapon of mass destruction atau sebagai "reaktor nuklir bergerak".

Artikel ini akan berupaya menjawab pertanyaan tentang bagaimana strategi maritim dua negara besar di Asia, yaitu China dan India di Selat Malaka? serta bagaimana persaingan strategi maritim dua negara di Selat Malaka?.

\section{Landasan Konseptual}

\section{Strategi Maritim}

Kajian strategi pada awalnya muncul dari evolusi definisi perang dan cara memenangkan perang dengan penggunaan kekuatan militer. Dibandingkan definisi awal yang tersirat dari pemikiran Karl Von Clausewitz dalam Joesoef (2014) tentang strategi “....strategy, the use of engagements for the object of war...", definisi yang lebih inklusif tentang strategi dipaparkan oleh Luttwak, "the art and science of developing and using political, economy, psychological and military forces as necessary during peace and war, to afford the maximum support to policies..". Sebagai bagian dari studi keamanan dan pertahanan, esensi dari konsep "strategi" adalah pada pendekatan pilihan rasional dan politis dalam mengambil kebijakan-kebijakan yang tercermin pada hubungan antara cara/alat (means) dengan tujuan (ends) yang terus menerus menyempurnakan upaya pertahanan dan keamanan negara. Dalam lingkup maritim, pada hakikatnya strategi maritim mengacu kepada pembentukan kekuatan laut (sea power) seperti halnya juga signifikansi penegakan kekuatan daratan (land power). Dengan kata lain, strategi maritim mengandung dua pemikiran pokok yaitu penegakan kontrol atas lautan dan eksploitasi kontrol lautan tersebut ke arah penegakan kontrol atas daratan. (Joesoef, 2014: 96-97).

Oleh karena itu, strategi maritim modern tidak hanya merujuk hanya pada kekuatan angkatan laut dan strategi angkatan laut semata, melainkan strategi yang menggabungkan kekuatan laut, darat dan udara dalam upaya kontrol dan mempengaruhi situasi -situasi di daerah pertahanan pesisir negara, sebagai wujud aktivitas pertahanan di perairan laut dalam (blue water maritime).

Ada tiga elemen penting dalam strategi maritim, yaitu sea control, sea denial dan maritime power projection (www.aph.gov.au). Elemen pertama Sea control, ialah sebuah kondisi penguasaan penuh suatu negara terhadap area maritim atau lautnya untuk melakukan sebarang aksi. Negara mempunyai kebebasan untuk menggunakan laut tersebut sesuai tujuannya (freedom to use) sekaligus jika diperlukan, menolak pihak lain yang berupaya menggunakan laut tersebut. Elemen kedua yaitu sea denial, yaitu kondisi yang lebih memfokuskan pada penolakan kepada pihak lawan untuk menggunakan perairan tertentu dalam jangka waktu tertentu pula. Aktivitas sea denial ini misalnya mencakup blokade terhadap kekuatan lawan dalam penggunaan jalur laut untuk kepentingan perdagangan. Sebuah negara secara simultan 
bisa menggabung sea control dalam satu area sekaligus sea denial di area lain, dan hal ini memberikan kebebasan suatu negara untuk bermanuver di dalam area perairannya. Elemen ketiga adalah maritime power projection, adalah kemampuan dan kekuatan militer negara di bidang maritim untuk melakukan ekspedisi perang dalam upaya deterrence (menggentarkan lawan), ancaman maupun pengiriman sinyal peperangan. Termasuk kekuatan dalam hal modernisasi teknologi persenjataan serta ketersediaan juga kelayakan alat utama sistem senjata (alutsista).

Strategi maritim China dan India sebagai negara pengguna di Selat Malaka hanya terbatas kepada penggunaan hukum "transit passage" 2 dan manajemen keamanan pelayaran (SLOC dan SLOT) di sepanjang jalur Selat Malaka. Salah satu upaya strategi maritim China dan India di Selat Malaka adalah upaya proyeksi militer maritim mereka yang dengan menggandeng beberapa kekuatan dan negara-negara Asia Tenggara untuk deterrence dan pengepungan perluasan strategi maritim pihak lain.

\section{Balance of Power dan Security Dilemma}

Konsep balance of power ini menitikberatkan pada manajemen kontrol kekuatan suatu negara terhadap negara lain dalam upayanya mempertahankan, meningkatkan keamanan atau mengimbangi kekuatan pihak lawan (Nye, 2005; Goldstein\& Pevenhouse, 2007). Setiap usaha peningkatan kekuatan pertahanan suatu negara akan direspon oleh negara lain dengan strategi peningkatan keselamatan, dan situasi ini disebut sebagai security dilemma (Herz, 1950).

Selama konteks internasional dipersepsikan anarki, hubungan antar negara selalu dipenuhi dengan kecurigaan dan kesalahapahaman. Karena itu, setiap negara bersaing dalam meningkatkan kapasitas dan kekuatan militernya untuk menjadi yang terbaik dalam peningkatan kekuatan pertahanan dalam ketidakpastian keamanan sistem internasional.

Konsep balance of power mempunyai tiga cakupan kajian, yaitu: Balances as distribution of power, balances of power as policy dan balance of power as multipolar system (Nye, 2005: 62). Balances as distribution of power terutamanya berkaitan dengan usaha terus menerus satu pihak dengan pihak lain untuk masing-masing meningkatkan kekuatannya dipicu oleh dilemma keamanan sehingga tidak ada satu pihak yang menjadi hegemon tunggal. Hal ini memang memicu perlombaan senjata (arm race) namun justru dalam keadaan ini, menurut realisme defensif

\footnotetext{
${ }^{2}$ Rezim transit passage, adalah rezim kompromi dari konsepsi "free transit" dan "innocent transit", yaitu rezim pelayaran yang memberikan kebebasan untuk lewat bagi kapal-kapal pengangkut dan kapal-kapal terbang asing untuk berkomunikasi dari bagian laut bebas (Zone Ekonomi Eksklusif, ZEE) ke laut bebas ZEE lainnya (pasal 38 ayat 2 UNCLOS). Konsepsi free transit menekankan perlunya kapal, termasuk kapal perang dan kapal selam untuk secara bebas dapat melewati perairan selat itu. Sedangkan konsepsi innocent passage menekankan pertimbangan tentang pentingnya pemeliharaan kepentingan negara pantai karena, menurut hukum internasional yang ada waktu itu (Geneva Convention, 1958), pelayaran kapal-kapal asing melalui laut wilayah harus innocent terhadap negara pantai. Misalnya, kapal selam harus berlayar di permukaan air.
} 
akan terwujud stabilitas keamanan. Dalam konteks balances of power as policy, ialah mencakup aktivitas atau perilaku negara dalam menghadapi sumber ancaman. Negara bisa melakukan aktivitas bandwagoning (menginduk kepada sumber ancaman yang lebih besar), atau balancing (melakukan aliansi dengan pihak lain yang lebih kecil untuk melawan sumber ancaman).

Dalam konsep balance of power, juga dikenal konsep containment policy dan detterence, jika aliansi yang dilakukan negaranegara tertentu melahirkan kebijakan pengepungan atau penghambatan terhadap proyeksi perluasan pengaruh dan kekuatan pihak lain, atau upaya menimbulkan efek gentar. Sedangkan Balance of power as multipolar systems, ialah ketika terjadi distribusi kekuasaan yang mendekati seimbang paska perang dingin ketika sistem internasional tidak lagi berupa bipolar atau unipolar melainkan multipolar, yang ditandai dengan bangkitnya negara-negara besar seperti China, Jepang, Rusia, dan India, juga institusi regional Uni Eropa (Waltz, 2000: 29-30).

Strategi Maritim China di Selat Malaka: antara "Malacca Dilemma" dan "String of Pearls”

Kepentingan China di Asia Tenggara ditandai sejak awal tahun 1990an melalui kebijakan "good neighbourliness" atau (mulin zhengce), China berupaya menguatkan hubungan dengan negara-negara di Asia Tenggara melalui ASEAN paska tragedi
Tiananmen 1989 (Kuik, 2005). Kebijakan ini tidak hanya dilandasi aspek ekonomi berkaitan dengan agenda kebangkitan kekuatan ekonomi China tetapi juga untuk keperluan membangun imej positif sebagai "responsible power". Imej ini diharapkan menjadi alat efektif dalam mendapatkan tujuan politik luar negeri dan sebagai sine qua non, upaya meminimalisir "china threat theory" dalam aspek ekonomi dan keamanan, serta mengefektifkan penggunaan "soft power"nya (Kuik, 2005: 113 -114). Soft power ini mencakup upaya-upaya untuk mendapatkan keuntungan-keuntungan ekonomi serta penyebaran norma dan nilai melalui kerjasama pada isu-isu non-tradisional, kerjasama pariwisata dan pendidikan, diplomasi, dan penguatan jaringan diaspora masyarakat China (Percival, 2007).

Untuk mengetahui lebih lanjut mengenai strategi maritim China, terlebih dahulu mesti melihat kebijakan pertahanan keamanan China. Berdasarkan buku putih pertahanan China tahun 2008, sektor pembangunan ekonomi dan sektor strategi pertahanan menjadi prioritas yang saling melengkapi. Hasil dari pembangunan sektor ekonomi diproyeksikan digunakan untuk mendukung pengembangan dan modernisasi sektor pertahanan dan militer dengan tujuan mengamankan wilayah. Bahkan dalam grand strategy China disebutkan bahwa negara berpenduduk lebih dari satu milyar ini berambisi menjadi kekuatan militer dan ekonomi di Asia Pasifik (Kanwal, 2008).

China berupaya untuk menjadi negara 
dengan kekuatan maritim dan kekuatan darat yang kuat. Oleh sebab itu, China juga mengembangkan strategi maritimnya pada tahun 1996, dengan menyusun “Ocean Agenda 21 " yang memfokuskan kepada pengembangan seluruh aset-aset maritim dan sumber daya (resources). Titik tekan pertahanan China adalah pada penguasaan wilayah, terutama wilayah-wilayah maritim yang masih bersengketa hingga kini, salah satunya di Laut China Selatan. Kepentingan China terhadap Laut China Selatan juga ditandai dengan meningkatnya aktivitas angkatan laut China di seputaran pulau Kuril dekat Jepang hingga ke Ryuku, Taiwan, Phipilina dan Kalimantan.

Selama Perang Dingin, China mengadopsi strategi pertahanan maritim yang didasarkan pada perlindungan terbatas pada perairan di darat dan pantainya (brown water navy dan green water navy). ${ }^{3}$ Angkatan Laut China, the People's Liberation Army Navy (PLAN) mengadopsi doktrin angkatan laut Uni Soviet (sekarang Rusia) untuk menggunakan kapal-kapal selam, kapal torpedo dan kapal pantai lainnya namun hanya beroperasi di dalam batas-batas pantai. Setelah Perang Dingin, China mulai memodernisasi angkatan lautnya serta mengubah strategi maritim dari brown-water dan green water navy menuju blue-water navy yang beroperasi perairan pantai ke perairan internasional dan laut China Selatan, dari pertahanan angkatan laut yang pasif ke pertahanan angkatan laut aktif (Mokhzani Zubir \& Mohd Nizam Bashiron, 2007).

Berkaitan dengan kepentingan China di Selat Malaka, China menghadapi apa yang dinamakan "Malacca Dilemma". Negara atau kekuatan eksternal yang mengontrol Selat Malaka hingga ke Samudera Hindia dipersepsikan oleh China bisa mengancam rute pasokan energinya (energy security). Dilema yang dihadapi China adalah, dibalik ketergantungan China yang tinggi pada terkawalnya keamanan Selat Malaka, disisi lain China tidak boleh melakukan pengawalan yang optimal dan efektif seperti yang China mau. Secara kapabilitas, angkatan laut China memang kuat, namun aktivitas angkatan laut China tidak boleh secara politis dan militeris melakukan manuver berlebih di Selat Malaka. Sebagai laut territorial dan bukan laut bebas (high seas), kedaulatan Selat Malaka masih milik negara-negara pantai (Indonesia, Malaysia dan Singapura). Dengan pengerahan kekuatan militer dan juga mengingat agresifitas China dalam beberapa kasus di Laut China Selatan dan isu Taiwan, bisa jadi menimbulkan “dilema keamanan”, sea denial, atau konflik bahkan dari negara-negara besar lain.

Meskipun begitu, strategi maritim China dalam mengamankan lalu lintas jalur lautnya dari Afrika hingga ke laut China

\footnotetext{
${ }^{3}$ Brown water navy adalah setiap kekuatan angkatan laut yang memiliki kapasitas untuk melakukan operasi militer di sungai atau pesisir pantai dengan kapal kecil dan kapal patroli. Sedangkan green water navy adalah kekuatan angkatan laut yang dirancang untuk beroperasi di zona littoral negara dan memiliki kompetensi untuk beroperasi di lautan terbuka di sekitarnya.
} 
Selatan ialah melalui strategi "String of Pearls" dimulai dengan pembangunan pelabuhan-pelabuhan sejak tahun 2002. Strategi "Strings of Pearls" ini mendeskripsikan manifestasi dari meningkatnya pengaruh geostrategik dan geopolitik China melalui upaya meningkatkan atau membangun pelabuhan dan lapangan udara di negara-negara tertentu, mengembangkan hubungan diplomatik khusus, dan memodernisasi pasukan militer khusus untuk mengamankan jalur laut yang membentang dari Laut China Selatan melalui Selat Malaka, Samudera Hindia, hingga ke Teluk Persia. Hal ini dibarengi dengan modernisasi angkatan militer, terutamanya angkatan udara (People's Liberation Army Air Force (PLAAF)) dan angkatan laut (People's Liberation Army Navy (PLAN)).

China membangun pelabuhanpelabuhan di Gwadar (Pakistan), Chittagong (Bangladesh), Hambantota (Srilanka), Sittwe (Myanmar), dan Kra (Thailand) dengan membuat jaringan pipa energi by pass melalui jalur darat, membuat jalur kereta api, atau membuat jaringan kanal terdekat dengan perairan di sekitarnya. China juga membangun fasilitas-fasilitas pertahanan di Pulau Coco yang hanya berjarak 18 mil dari pangkalan angkatan laut India di pulau Andaman dan Nicobar (Vavro, 2008). Konsekwensi dari hal ini pembangunan-pembangunan ini bagi India ialah, lalu lalang kapalkapal tanker besar milik China di sekitar kepulauan Andaman dan Nicobar, bisa digunakan sebagai sarana mematai-matai (intelligence) melawan India.

Strategi maritim China dalam penggunaan soft power China di Asia Tenggara juga terlihat dari upayanya menjalin kerjasama dalam ASEAN Regional Forum $(A R F)$. China juga aktif menggelar diskusi mengenai keselamatan maritim di Asia Tenggara dalam forum ARF Round Table Discussion on StocktakingofMaritimeSecurity Issues. (Lum et al, 2008). China juga mengklaim mempunyai prinsip pasifis dan non -ekspansionis, meskipun kemudian strategi ofensif dan serangan pre-emptive bisa saja dilakukan China dan diklasifikasikan sebagai "self-defense counterattack" (ziwei fanji). Terutamanya menyangkut hubungannya dengan Amerika Serikat. Perkembangan strategi maritim China selanjutnya ialah penggunaan aktor-aktor non negara sebagai lingkaran pengamanan maritim. Penggunaan kapal-kapal non militer dalam perusahaan China Overseas Shipping Company (COSCO) yang mempunyai hubungan dekat dengan PLAN menjadi wujud strategi yang asimetris dan unconventional (Khurana, 2009:57).

\section{Strategi Maritim India di Selat Malaka: upaya Blokade terhadap China}

Sebagai negara yang kuat di kawasan, kekuasaan maritim India ingin ditingkatkan terutamanya mencakup perluasan area maritim dan agenda angkatan laut melalui "blue water navy" untuk tidak hanya mencakup samudera Hindia saja. Hal ini tercermin dalam doktrin maritim India "...envisages an ambient forward naval presence from the Strait of 
Hormuz to the Strait of Malacca" (Vavro, 2008: 17). Setelah kemerdekaan India pada tahun 1947, Perdana Menteri Jawaharlal Nehru ketika itu terpengaruh oleh doktrin strategi Ghandi untuk membuat kebijakan keamanan dan pertahanan sebagai cerminan kepentingan nasional India. Dalam menyikapi situasi politik Perang Dingin, Nehru mengembangkan doktrin tentang hidup berdampingan secara damai (peaceful co-existence) dalam menyikapi sikap politik agresif China. Selama Perang Dingin juga, India menjadi oposisi bagi blok-blok yang bertikai. Hal ini dibuktikan dengan keterlibatan India sebagai salah satu penggagas Non-Allignment Movement. Namun dengan berakhirnya Perang Dingin dan pertumbuhan ekonomi yang melaju pesat, India mengembangkan kebijakan luar negeri dan pertahanan yang lebih aktif. India menjadi lebih dekat kepada AS untuk mengimbangi ancaman pengembangan nuklir Pakistan dan juga mengatasi dilemma keamanan terhadap perluasan pengaruh China. Mengingat beberapa sengketa perbatasan serta konflik etnis (konflik simetris dan asimetris) yang melibatkan dua negara China dan Pakistan ini masih mengemuka hingga sekarang.

Seperti halnya China, India sebagai responsible power juga melihat Asia Tenggara dalam cakupan objek kebijakan regional dengan menitikberatkan pada penggunaan soft power. Doktrin Gujral tahun 1998 di kawasan Asia Selatan misalnya, menyebutkan tentang prinsip timbal balik, bahwa India mempunyai tanggungjawab yang lebih besar dan seyogyanya membantu negara tetangga yang lebih kecil dalam penguatan hubungan ekonomi, politik dan keamanan (Schmidt, 2011). Sedangkan di kawasan Asia Tenggara, Implementasi kebijakan Look East Policy India di tahun 1991 dalam pemerintahan PM Narasimha Rao menjadi landasan bagi negara ini untuk menjalin hubungan dengan negaranegara Asia Tenggara termasuk juga kerjasama angkatan lautnya. Kebijakan Look East Policy yang sekarang berganti nama menjadi Act East di bawah kepemimpinan PM Narendra Modi mempunyai muatan yang sama terutamanya utuk menguatkan hubungan dengan Asia Tenggara dalam kepentingan ekonomi dan counter terhadap pengaruh China (Jacob, 2014, diakses dari: $\underline{\text { http:// }}$ www.hindustantimes.com/india-news/ndaaims-at-deeper-engagement-with-asiancountries/article1-1271765.aspx).

Kaitannya dengan strategi maritim, dalam dokumen strategi maritim India disebutkan bahwa area grand strategy maritim India melingkupi samudera Hindia bagian utara hingga selatan sampai ke Samudera Pasifik selatan melalui Selat Malaka. Dalam dokumen strategi militer maritim India memberi panduan mengenai prinsip-prinsip yang harus dilakukan dan menghasilkan kerangka-kerangka protektif dalam penggunaan lautan (sea control) dalam segala aspek demi keuntungan nasional. Strategi militer maritim ini terutamanya mesti dilakukan oleh angkatan laut India bekerjasama dengan angkatan darat dan 
beberapa institusi pemerintah terkait.

Sebagai salah satu negara pengguna, India juga berkepentingan dalam keamanan jalur laut Selat Malaka, terutamanya terhadap potensi ancaman dan gangguan di area maritim India sendiri seperti di Samudera India dan laut Andaman. Kewaspadaan India terhadap perluasan kekuatan China di Asia Tenggara dan kegelisahan mengenai ekspansi militer China hingga ke samudera Hindia, menjadi alasan India untuk membuat strategi maritim dengan power projection membangun Far Eastern Naval Command (FENC) atau Komando terpadu Andaman Nicobar (Andaman Nicobar Command/ANC) di pelabuhan Blair di tahun 2001. Pembangunan ANC ini juga dibantu oleh Amerika Serikat sebagai aliansi strategis di Asia Tenggara dalam politik pembendungan terhadap China.

Upaya ini dilakukan untuk menyatukan angkatan darat, laut dan udara di bawah satu arahan struktur untuk meningkatkan jangkauan maritim serta memperketat pengawasan terhadap jalur dari Selat Melaka hingga ke teluk Benggala. India juga melakukan peremajaan/upgrade pangkalan di pulau Andaman dan Nicobar. Modernisasi kapabilitas maritim India juga meningkat terlihat dari modernisasi kapal-kapal laut dengan bermacam varian, kapal bawah laut, persenjataan mesiu presisi terpadu (precisionguided munitions/PGMs) maupun sistemsistem intelejen, kontrol dan komando (Singh, 2008:58).

Analis kajian maritim, Zhang Min (dalam Rai, 2009, diakses dalam: http:// www.indiandefencereview.com/news/chinasstring-of-pearls-vs-indias-iron-curtain/), mengatakan bahwa pembangunan ANC ini adalah upaya tirai besi atau 'metal block' di Samudera Hindia, memblokade akses China terutamanya untuk melewati Selat Malaka.

Selain melakukan upgrade pelabuhanpelabuhan di Andaman dan Nicobar, India juga membangun pangkalan udara untuk memonitor keamanan lalu lintas di sekitar teluk Benggala hingga ke Selat Malaka. India juga meningkatkan hubungan aliansi dengan Jepang, Vietnam dan Singapura serta latihanlatihan perang kapal laut (naval exercises) dengan US Navy (Vavro, 2008:17).

India juga menggunakan angkatan lautnya untuk keterlibatan politik-diplomatik dengan negara-negara pantai. Satu hal yang penting adalah penggunaan pertama kali kapal induk INS Viraat yang melalui Selat Melaka pada tahun 2005. Kapal tersebut melakukan kunjungan ke Port Klang (Malaysia) diteruskan ke Singapura dan Jakarta (Indonesia). Pada tahun 2006 dalam dialog Shangri-la, kementerian pertahanan India menawarkan bantuan atau kapasitas lain untuk membantu menambah keamanan Selat Melaka. Angkatan laut India juga ikut dalam koordinasi patroli laut dengan Indonesia sejak 2001 (Patkor Indindo) dan Thailand sejak 2005, juga kerjasama yang sama dengan Myanmar dan Malaysia.

\section{Aktivitas dan Persaingan Strategi Maritim}




\section{China dan India di Selat Malaka}

Kedua negara India dan China ialah negara dengan Comprehensive National Power (CNP) yang besar selaras dengan kebangkitan ekonomi dan militernya, serta menjadi kekuatan regional di masing-masing kawasan, Asia Selatan dan Asia Timur. Masing-masing negara juga mempunyai ambisi untuk menjadi hegemon regional. Tellis (dalam Khurana 2011;61) mengatakan secara lebih jelas bahwa India potensial menjadi rival China dalam proyeksi keamanan jangka panjang, “India's emerging economic strength and its geophysical location make it relevant to China's long-term security . . India could become a major regional rival for influence in Central and Southeast Asia and in the Persian Gulf."

China dan India juga mempunyai doktrin maritim yang sama dalam penguasaan lautan melalui proyeksi "blue water navy". India mempunyai area maritim di samudera Hindia yang menjadi jalur penghubung eksporimpor barang dari Afrika dan Timur Tengah menuju ke Asia Tenggara, Asia Timur dan Asia Pasifik. Begitupun dengan China yang mempunyai area atas Laut China Selatan atau bagian Barat Samudera Pasifik. Sedangkan kepentingan strategis kedua negara di lautan dapat bertemu, berbenturan ataupun berkompetisi di Selat Melaka sebagai selat penghubung samudera Hindia dan samudera Pasifik.

Menyangkut hubungannya dengan Selat Malaka, persaingan China dan India terjadi secara tidak langsung, mengingat Selat
Malaka adalah wilayah yurisdiksi negaranegara pantai (territorial sea). Namun begitu, artikel 43 UNCLOS 1982 menyebutkan bahwa negara pengguna (user states) berkewajiban membantu (burdens sharing) ${ }^{4}$ dengan negara pantai dalam meningkatkan keamanan dan keselamatan (security and safety) navigasi, pelayaran dan komunikasi.

Dalam konteks soft power menyangkut kerjasama dengan negara pantai, India dan China sama-sama membantu negara-negara pantai. Sebagai contoh, China dengan the Nippon Foundation dari Jepang, berkontribusi dalam kerjasama Tripartit Technical Expert Group (TTEG ) bersama Malaysia , Indonesia dan Singapura. Sedangkan India juga tak mau kalah, berkontribusi dalam memberikan bantuan dana kepada TTEG dan membantu dalam aktivitas survey bangkai kapal di Selat Malaka, yang dipersepsikan sebagai "red flag" kepada China dalam 'mengambil hati' negaranegara pantai (Rai, 2009, "China's String of Pearls vs India's Iron Curtain", diakses dari: http://www.indiandefencereview.com/news/ chinas-string-of-pearls-vs-indias-iron-curtain/).

Namun kedua negara China dan India masih belum optimal dalam memberikan bantuan. Disebutkan bahwa tidak ada user states selain Jepang yang secara optimal dan terus-menerus membantu negara pantai dalam meningkatkan keselamatan pelayaran, termasuk keamanan, dan memelihara lingkungan laut dari pencemaran (Djalal, 2014, "Persoalan Selat Malaka-Singapura", diakses dari; $\quad$ http://www.setneg.go.id/index.php? 
option $=$ com content\&task=view\&id $=22$.

Peningkatan aktivitas angkatan laut India di ANC justru dianggap (terutama oleh China) semakin meningkatkan potensi India untuk melakukan misi-misi militer atau manuver-manuver militer di Selat Malaka. Tentu saja hal ini menyebabkan ketidaknyamanan China, ketika beberapa analis China menyebutkan bahwa perkembangan proyeksi maritim India adalah wujud dari hasrat India untuk menjadi "penjaga" Selat Malaka, dimana China tidak menyetujui ini (Khurana, 2009\& Xuegang, 2007).

Pandangan yang sama juga dikemukakan oleh para pembuat kebijakan strategi India, bahwa mereka mencurigai dan tidak menyetujui terhadap ambisi China untuk menjadi "great power" di Selat Melaka. Peningkatan dan aktivitas militer China (PLAN) di kawasan Asia Tenggara (Selat Malaka dan samudera Hindia) juga menimbulkan kecurigaan dan ketegangan di kawasan, terutamanya oleh negara-negara di Asia Tenggara, juga oleh negara-negara besar seperti India, Jepang dan Amerika Serikat, khususnya menyangkut kebebasan navigasi (freedom of navigation).

Strategi maritim China kemudian menciptakan lembaga penjaga pantai terpadu (unified coast guard agency). Langkah ini berpotensi memperkuat kapasitas China dalam menggunakan kapal-kapal non - militer untuk mencapai tujuan dan pengaruh di Asia Tenggara. Strategi maritim India sendiri difokuskan dalam rangka persiapan untuk menghadapi, containment dan deterrence terhadap China. Selain peningkatan pembangunan persenjataan di ANC di kepulauan Andaman dan Nicobar, juga modernisasi Indian Navy, Di teluk Campbell bagian kepulauan Nicobar, India juga membangun pangkalan udara angkatan laut atau Naval Air Station (NAS) dengan pesawat besar C130J untuk kegiatan memata-matai (Indian's eyes) aktivitas maritim China, memonitor Teluk Benggala dan Selat Malaka (http://www.ndtv.com/article/india/counteringchina-india-s-baaz-to-spy-on-the-malaccastrait-241492).

Mengingat area maritim kedua negara, dan aktivitas China dalam strategi "string of pearls", zona kepentingan maritim India dan China bisa saja overlapping, meskipun masingmasing mempunyai penekanan motif strategi yang berbeda. Kita tahu bahwa Selat Malaka mempunyai keterbatasan. Selat Melaka terbentang lebih kurang $900 \mathrm{~km}$ dari titik terlebar (widest point); lebih kurang $350 \mathrm{~km}$ antara utara Sumatera dan Thailand; dan untuk yang sempit, kurang daripada $3 \mathrm{~km}$ antara Sumatera Selatan dan Singapura. Selat Melaka

\footnotetext{
${ }^{4}$ Pasal 43 dari UNCLOS telah mengatur "burden-sharing agreements" antara negara-negara pesisir dan negara-negara pengguna dalam: (1) Penyediaan dan pemeliharaan alat bantu navigasi. (2) Sistema komunikasi.( 3) Hidrografis dan informasi navigasi lainnya. (4) SAR. (5) Keamanan pantai. (6) Pelayanan penyelamatan dasar untuk kapal. (7) Pengaturan kontingensi polusi laut. (8) Terkait burden sharing, yang masih terdapat grey area terkait dengan mekanisme "biaya pemulihan" dari negara-negara pengguna.
} 
pun dilaporkan hanya mempunyai kedalaman 25 meter. Keterbatasan Selat Malaka ini juga membuat negara-negara besar, terutama China dan Amerika Serikat tidak bisa dan tidak boleh secara massif melakukan "show-off" kekuatan maritimnya.

Meskipun begitu, Asia Tenggara memanglah menjadi arena pertarungan kekuatan sekaligus objek perebutan pengaruh ketika China berusaha melakukan balancing terhadap Amerika Serikat dan India, atau sebaliknya balancing yang dilakukan India terhadap China dan Amerika Serikat. Perlu dilihat bahwa Upaya AS untuk memperluas kapabilitas dalam perancangan penggunaan pasukan secara lintas wilayah juga bisa mengancam stabilitas kawasan samudera Hindia sekaligus mengancam posisi India di samudera Hindia (Singh, 2008:47).

\section{Penutup}

Strategi maritim China dan India sebenarnya mempunyai konvergensi terutamanya menyangkut kepentingan kedua negara untuk ikut serta burden sharing dalam pengamanan Selat Malaka bersama dengan negara-negara pantai serta upaya memerangi kejahatan maritim. Kerjasama angkatan laut India dan China pun juga masih dilakukan terutamanya untuk mengatasi tantangan keamanan non-tradisional melalui operasi antipiracy di Selat Malaka dengan cara berbagi informasi dan data intelejen.

Strategi maritim China di Selat Malaka adalah satu bagian dari strategi "string of pearls" terutamanya untuk menjaga keamanan lalu lintas sumber energi. Namun, China juga mempunyai "Malacca dilemma" yang membuatnya tidak optimal dalam proses pengamanan kepentingan maritim di selat ini. Belum lagi jika berkaitan dengan agresifitas pertahanan China yang terlihat dari isu Taiwan dan konflik Laut China Selatan, membuat kecurigaan dan "ketakutan" beberapa negara di Asia Tenggara dan juga negara-negara besar yang juga mempunyai kepentingan di Asia Tenggara, khususnya Selat Malaka, terutamanya Amerika Serikat, Jepang dan India.

Sebuah blessing in disguise bagi negara -negara di Asia Tenggara ketika China's factor menjadi salah satu pendorong meningkatnya hubungan India dengan negara-negara Asia Tenggara. Mengingat aktivitas dan sekaligus agresifitas China di kawasan Asia Tenggara (kasus Laut China Selatan) dengan postur kuatnya pada penegakan dan konsolidasi teritori, agaknya negara-negara di Asia Tenggara beruntung bahwa skema "balance of power" antar negara-negara besar setidaknya bisa menjaga kestabilan kawasan atau tidak melahirkan hegemon baru, seperti apa yang Kenneth Waltz katakan melalui perbedaan perspektif defensive realism dan offensive realism dalam situasi anarkhi.

Dalam pergulatan pengaruh, kedua negara telah menggunakan berbagai cara, dari kerjasama ekonomi hingga kerjasama pertahanan dan angkatan laut dengan negaranegara pantai maupun negara-negara lain di Asia Tenggara. Hal ini menjadi insentif 
tersendiri bagi negara-negara pantai mengingat ancaman keamanan non-tradisional menyangkut transnational organized crime di Selat Malaka juga masih mengemuka. Hanya saja, negara-negara besar di kawasan ini juga mesti menghormati hak-hak negara pantai apalagi menyangkut kedaulatan littoral states. Semua negara juga mesti menghormati hukum laut UNCLOS 1982 dalam bertanggungjawab dan membantu keselamatan, keamanan navigasi serta kelangsungan ekosistem di selat Malaka bersama negara-negara pantai. Termasuk juga secara politis, membantu stabilitas keamanan, tidak berupaya melakukan provokasi, serta menghormati Treaty of Amity and Cooperation maupun tetap men-support Zone of Peace, Freedom and Neutrality (ZOPFAN) di Asia Tenggara. 


\section{Daftar Pustaka}

Chwee, Kuik Cheng. "Multilateralism in China's ASEAN Policy: Its Evolution, Characteristics, and Aspiration". Contemporary Southeast Asia 27. No. 1 (2005): 102-22.

Gerard, Graham \& Ong-Webb. Piracy, Maritime Terrorism and Securing the Malacca Straits. Singapore: Institute of Southeast Asian Studies. 2006.

Goldstein, Joshua S \& Pevenhouse, Jon C. International Relations: Brief Edition 2006-2007. New York: Pearson Longman. 2007.

Herz, John H. "Idealist Internationalism and Security Dilemma”. World Politics (Vol.2). 1950.

Jha, Pankaj Kumar. "India's Defence Diplomacy in Southeast Asia”. Journal of Defence Studies. Vol 5. No 1. January 2011.

Joesoef, Daoed. Studi Strategi: Logika Ketahanan dan Pembangunan Nasional. Jakarta: Penerbit Buku Kompas. 2014.

Kanwal, Gurmeet. "China's Defence Strategy and Military Posture” dalam Jasjit Singh. A sian Defence Review 2007. New Delhi: KW Publishers Pvt.Ltd.

Khurana, Cdr Gurpreet S. "China's Maritime Strategy and India: Consonance

and Discord", Maritime Affairs: Journal of the National Maritime Foundation of India, 7:2, 5065. 2011.

Kusuma, Ayusia Sabhita. "Securing Indonesia's Sovereignty in the Sea: Focusing First on Malacca Strait", Prosiding International Conference on International System "The End of Westphalian?: Contemporary Global Challenges Toward the Nation-State System". 9 November 2013. Universitas Muhammadiyah Yogyakarta, Indonesia

Lum, Thomas, Morrison, Wayne M \& Vaughn, Bruce ."China's Soft Power in South East Asia". CRS Report for Congress. 4 Januari 2008. 
Mokhzani Zubir \& Mohd Nizam Bashiron. The Straits of Malacca: the Rise of China, America's Intentions and the Dilemma of the Littoral States. Kuala Lumpur: Maritime Institute of Malaysia. 2007.

Nye, Joseph S. Understanding International Conflicts: an Introduction to Theory and History. New York. 2005.

Percival, Bronson. The Dragon Looks South: China and Southeast Asia in the New Century. Wesport: Praeger Publishers. 2007.

Prabhakar, W. Lawrence S. "Maritime security triangulation of ASEAN-Australia-India: An Indian Perspective". dalam William T. Tow and Chin Kin Wah (ed.). ASEAN India Australia: Towards Closer Engagement in A New Asia. Singapore: ISEAS. 2009.

Sawhney, R. "Redefining the Limits of the Straits: A Composite Malacca Straits Security System.” RSIS Commentary 37/2006. (Singapore: S. Rajaratnam School of International Studies) 2006; dan Arsyad, R. "Cooperation to Safeguard Shipping through the Malacca Strait," dalam A. Forbes. ed. Papers in A ustralian Maritime Affairs, No. 23(Canberra: Sea Power Centre Australia). 2008.

Schmidt, Johannes Dragsbaek. "India China Rivalry and Competition in Southeast Asia", First draft paper for the international Conference "India in International Relations: European and Indian perspectives”, 27-29 April, 2011, Delhi, India.

Singh, K.R. 2008. Maritime Security for India:New Challenge and Responses. New Delhi: New Century Publications.2008.

Singh, Inderjit a/l Singh, Tara. "Safeguarding the Straits of Malacca Against Maritime Crimes. Issues Among States on Security Responsibility. International Journal of Humanities and Social Science. Vol. 2 No. 2 [Special Issue-January 2012].

Storey, Ian. “China's 'Malacca Dilemma”". China Brief. Jamestown Foundation (12 April 2006).

Vavro, Caroline. "Piracy, Terrorism and the Balance of Power in the Malacca Strait". Canadian Naval Review. Vol. 4 Number.1, (Spring 2008).

Waltz, Kenneth. “Structural Realism After the Cold War”. International Security. 25:1 (2000).

Watkins, James D. USN. The Maritime Strategy. Annapolis Maryland: United States Naval Institute Press. 1986.

Xuegang, Zhang . "Southeast Asia and Energy: Gateway to Stability", China Security. Vol 3(2), Spring 2007.

\section{Sumber Internet:}

“australia's maritime strategy", Diakses dari: http://www.aph.gov.au/parliamentary business/ committees/house_of_representatives_committees?url=jfadt/maritime/report/chapter2.pdf. 
"Countering China: India's Baaz to spy on the Malacca Strait", diakses dari: http:// www.ndtv.com/article/india/countering-china-india-s-baaz-to-spy-on-the-malacca-strait241492.

Djalal, Hasjim. "Persoalan Selat Malaka-Singapura" , 14 Desember 2014, diakses dari; http:// www.setneg.go.id/index.php?option=com_content\&task=view\&id=22.

Jacob, Jayanth. "'Look East' policy is now 'Act East'” 4 Oktober 2014, diakses dari: http:// www.hindustantimes.com/india-news/nda-aims-at-deeper-engagement-with-asiancountries/article1-1271765.aspx

Khurana, Cdr Gurpreet S. China-India Maritime Rivalry. Diakses dari: http:// www.indiandefencereview.com/2009/04/china-india-maritime-rivalry.html.

Rai, Cmde Ranjit B. "China's String of Pearls vs India's Iron Curtain”, Issue Vol 24.4 OctDec2009, diakses dari: http://www.indiandefencereview.com/news/chinas-string-of-pearls-vsindias-iron-curtain/

Ramachandran, Sudha. "Delhi all Ears in the Indian Ocean," Asia Times Online, 3 March 2006, diakses dari: www.atimes.com.

"The China-India Border War", diakses dari http://www.globalsecurity.org http:// www.globalsecurity.org/military/library/report/1984/CJB.htm 